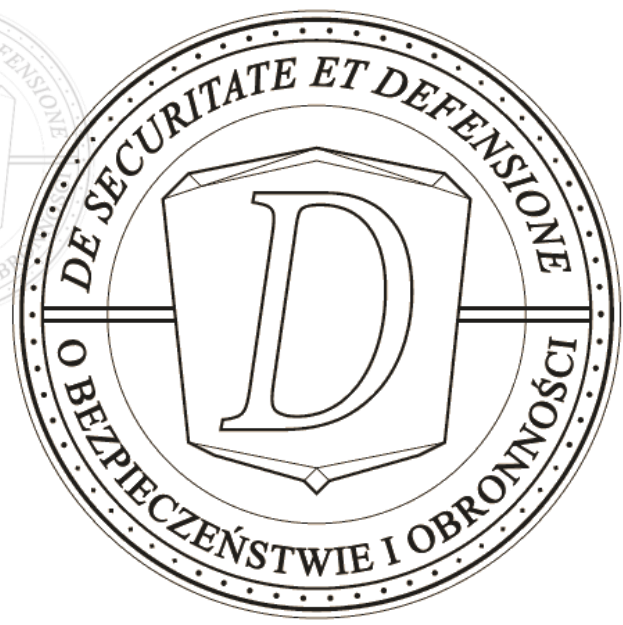

\title{
KONCEPCJA ROZWIĄZANIA MODELOWEGO DLA SYSTEMU BEZPIECZEŃSTWA PUBLICZNEGO DUŻEJ AGLOMERACJI MIEJSKIEJ
}

\begin{abstract}
AbSTRAKT: Przedmiotem niniejszego opracowania jest przedstawienie koncepcji rozwiązania modelowego dla systemu bezpieczeństwa publicznego aglomeracji monocentrycznej i policentrycznej. Biorąc pod uwagę uwarunkowania bezpieczeństwa dużej aglomeracji miejskiej przyjęto jeden uniwersalny schemat organizacji Policji. Jej funkcjonowanie w oparciu o określone formy i metody ogranicza do pewnego stopnia autonomię komendantów Policji w kształtowaniu bezpieczeństwa stosownie do specyfiki i wewnętrznych uwarunkowań społeczno-organizacyjnych danej aglomeracji. Spośród dostępnych metod badawczych wykorzystano w szczególności metodę obserwacji uczestniczącej. Niemniej jednak podstawową metodą naukową pozyskania danych empirycznych był sondaż diagnostyczny. Ponadto $\mathrm{w}$ artykule zaprezentowano opinię policjantów na temat przeniesienia rozwiązań z aglomeracji warszawskiej do innych aglomeracji w Polsce. Przedstawiono autorską propozycję koncepcji rozwiązania modelowego dla systemu bezpieczeństwa publicznego dużej aglomeracji miejskiej.
\end{abstract}

SŁOWA KLUCzOWE: policja, system bezpieczeństwa publicznego, aglomeracja monocentryczna, aglomeracja policentryczna, koncepcja

\section{THE CONCEPT OF A MODEL SOLUTION FOR THE PUBLIC SECURITY SYSTEM OF A LARGE URBAN AGGLOMERATION}

ABSTRACT: The subject of this study is to present the concept of a model solution for the public security system of monocentric and polycentric agglomeration. Taking into account the security conditions of a large urban agglomeration, one universal scheme of police organization has been adopted. Its functioning on the basis of specific forms and methods to some extent limits the autonomy of police chiefs in shaping safety in accordance with the specificity and internal social and organizational conditions of the agglomeration. Among the available research methods, the participatory observation method was used in particular. Nevertheless, the basic scientific method for obtaining empirical data was a diagnostic survey. Furthermore, the article presents the opinion of police officers on the transfer of solutions from the Warsaw agglomeration to other agglomerations in Poland. The author's conceptual proposal of a model solution for the public safety system of a large urban agglomeration was presented.

KEYWORDS: police, public safety system, monocentric agglomeration, polycentric agglomeration, concept

${ }^{1}$ Warsaw Police Headquarters; Poland. 


\section{WPROWADZENIE}

Pozycja Policji w systemie bezpieczeństwa publicznego kształtowała się różnie na przestrzeni wielu lat. Bez względu na podporządkowanie, strukturę oraz nazwę była to formacja uzbrojona, która służyła państwu oraz jego obywatelom. Jej priorytetowym celem była ochrona bezpieczeństwa oraz porządku publicznego ${ }^{2}$.

Rozważania w przedmiotowym opracowaniu skupiono na rozwiązaniu problemu zawierającego się w pytaniu: Jakie rozwiązania strukturalne i funkcjonalne umożliwiłyby konsolidację wysiłku Policji na rzecz bezpieczeństwa mieszkańców różnych typów aglomeracji? Utworzenie jednego silnego ośrodka policyjnego, uwzględniającego specyfikę wielkomiejską, umożliwiłoby sprawną realizację zadań z zakresu bezpieczeństwa publicznego w dużej aglomeracji miejskiej. W tym celu warto byłoby stworzyć komendy rejonowe lub okręgowe w dużych miastach, co mogłoby wpłynąć na usprawnienie struktury organizacyjnej, w których skupione byłyby siły i środki dotychczas rozproszone w wielu komendach.

Bezpośrednio na wybór tematu wpłynęły dwa zagadnienia, które - zdaniem Autorki wymagały rozwiązania, bądź szczegółowej analizy i uzupełnienia:

- brak rozwiązania strukturalnego oraz funkcjonalnego dla aglomeracji monocentrycznej i policentrycznej, w celu skutecznej realizacji zadań z zakresu bezpieczeństwa publicznego w dużej aglomeracji miejskiej;

- brak rozwiązania modelowego ukierunkowanego na konsolidację wysiłku Policji, a także optymalnego wykorzystania rozproszonych sił oraz środków pozostających w jej dyspozycji.

Specyfiką Policji jest jej hierarchiczność zarządzania oraz podporządkowanie jednostek szczebla niższego jednostkom wyżej usytuowanym w hierarchii. Rozwiązania organizacyjne systemu bezpieczeństwa publicznego w Warszawie opierają się na podobnym schemacie, który wynika z tego, iż cała organizacja oraz funkcjonowanie Policji w Polsce opiera się na tych samych przepisach. Przepisy nie uwzględniają w żaden sposób ,specyfiki dużych aglomeracji miejskich”, z wyjątkiem aglomeracji warszawskiej.

Możliwe jest stworzenie uniwersalnego rozwiązania modelowego dla systemu bezpieczeństwa publicznego dużej aglomeracji miejskiej - zarówno w przypadku aglomeracji monocentrycznej, jak i w przypadku aglomeracji policentrycznej - usytuowanego na szczeblu miasta wojewódzkiego. Porównanie struktur organizacyjnych komend Policji w aglomeracjach różnego typu pozwoliło wykazać, iż rozwiązania organizacyjne komend umiejscowionych w wielkich miastach opierają się na podobnym schemacie, co jest wynikiem oparcia organizacji i funkcjonowania Policji na tych samych regulacjach prawnych. Pomimo różnej wielkości miasta, jego statusu prawnego, rodzajów przestępczości czy zurbanizowania w poszczególnych miastach nie znajdziemy rozwiązań organizacyjnych w komendach, dopasowanych do stopnia

\footnotetext{
${ }^{2}$ S. Pieprzny, Policja. Organizacja i funkcjonowanie, Zakamycze 2003, s. 7.
} 
zagrożeń występujących na danym terenie. Takie rozwiązanie występuje jedynie w aglomeracji warszawskiej, gdzie komórki i wydziały w Komendzie Stołecznej Policji są dostosowane do zagrożeń występujących na jej obszarze. Ważną rolę odgrywają tu komendy rejonowe, podległe pod KSP. Realizują one swoje zadania na podstawie odrębnych regulaminów. Takie ustalenia, w połączeniu z pozytywną oceną możliwości przeniesienia rozwiązań obowiązujących w warszawskiej Policji do innych aglomeracji - taką opinię wyrazili funkcjonariusze i komendanci dały podstawy do kontynuowania prac nad wspomnianą wcześniej koncepcją.

\section{PoróWnaNie STRUKTUR ORgaNizaCYJNYCH PolicJi W AGLOMERACJACH RÓŻNEGO TYPU}

Struktura organizacyjna, tryb kierowania i zadania komórek organizacyjnych poszczególnych komend uregulowane są Regulaminem poszczególnych jednostek Policji. Regulamin jest podstawowym dokumentem, który odnosi się bezpośrednio do organizacji w każdej jednostce. W myśl przepisów ustawy z dnia 6 kwietnia 1990 r. o Policji regulaminy komend ustala właściwy komendant Policji w porozumieniu z przełożonym. Każda jednostka Policji w Polsce posiada swój odrębny regulamin, który jest formalną podstawą jej działania. W regulaminach określa się zakres zadań dla komórek, stanowisk oraz jednostek, sposoby realizacji obowiązków i tryb kierowania daną jednostką Policji. Ponadto zawarte w nich są postanowienia dotyczące szczególnie: struktury organizacyjnej, w tym dotyczące wszystkich poszczególnych komórek organizacyjnych, samodzielnych stanowisk oraz podległych jednostek. Struktura organizacyjna, a także etatowa jednostek Policji powinna zostać tak zbudowana przez każdego z komendantów Policji, żeby zapewnić sprawne funkcjonowanie jednostki na terenie swojego obszaru działania. Dodatkowo musi ona zapewniać realizację wszystkich stojących przed Policją zadań wchodzących w zakres działania jednostki oraz skutecznie przeciwdziałać pojawiającym się na danym terenie zagrożeniom ${ }^{3}$. Różnice oraz podobieństwa w zakresie specyfiki organizacyjnej właściwej dla danej komendy Policji, z uwzględnieniem konkretnych miast oraz gmin, zostały poddane analizie, syntezie oraz porównaniu.

Komendy Policji w Polsce umiejscowione w dużych miastach posiadają nieco odmienną organizację strukturalno-etatową, która zależna jest przede wszystkim od liczby ludności miasta, w którym funkcjonuje, jego obszaru oraz stanu zagrożenia przestępczością.

Analiza struktury organizacyjnej Komendy Stołecznej Policji w Warszawie wskazuje, iż jednostka ta oprócz typowych komórek, które powołane są do zwalczania zagrożeń funkcjonujących we wszystkich jednostkach Policji w Polsce, posiada w swojej strukturze nietypowe, specyficzne komórki. Ich celem jest zwalczanie zagrożeń ujawniających się przede wszystkim na

\footnotetext{
${ }^{3}$ Zarządzenie nr 1041 Komendanta Głównego Policji z 28 września 2007 r., wyd. cyt., § 30 i 31 - to szczegółowy wykaz zadań, jakie spoczywają na komendach powiatowych, w tym miejskich i komisariatach Policji.
} 
terenie miasta Warszawy ${ }^{4}$. Dodatkowo na terenie KSP funkcjonują również cztery komisariaty specjalistyczne, powołane jako odrębne jednostki policyjne, które mają na celu zwalczanie zagrożeń związanych z funkcjonowaniem określonej infrastruktury miejskiej, tj.:

- Komisariat Policji Portu Lotniczego Warszawa-Okęcie,

- Komisariat Policji Metra Warszawskiego,

- Komisariat Rzeczny Policji,

- Komisariat Kolejowy Policji.

Policja jest jednym z integralnych elementów systemu bezpieczeństwa publicznego, stanowiącego część systemu bezpieczeństwa narodowego. Policja w Warszawie zajmuje szczególne miejsce w tym systemie. Głównym determinantem wpisującym Policję w omawiany system jest zakres zadań, jakie nałożono na tę umundurowaną i uzbrojoną formację, za pośrednictwem obowiązujących aktów prawnych. W tak specyficznych uwarunkowaniach, jakie występują w m.st. Warszawa, sprawne zarządzanie tą formacją staje się dużym wyzwaniem.

W tym miejscu warto przybliżyć funkcjonowanie Policji w innych aglomeracjach państw europejskich. Dla przykładu - Belgia posiada niespotykany model Policji we współczesnej Europie. Są tam trzy rodzaje Policji: Policja municypalna ${ }^{5}$, składająca się z 16000 funkcjonariuszy, żandarmeria, składająca się z 15000 funkcjonariuszy, oraz Policja sądowa składająca się z 1400 funkcjonariuszy. Ochroną porządku oraz bezpieczeństwem publicznym zajmuje się żandarmeria i Policja municypalna ${ }^{6}$.

Policję francuską natomiast wyróżnia model ochrony i porządku publicznego mający charakter wielopodmiotowy zdecentralizowany. Francja posiada trzy systemy Policji: Policję Narodową, podlegającą ministrowi spraw wewnętrznych, Żandarmerię Narodową, podlegającą ministrowi obrony ${ }^{7}$, oraz Policje municypalne, podlegające merom ${ }^{8}$. Należy jednak wspomnieć, iż kompetencje Policji municypalnej są niewspółmiernie małe w stosunku do zadań merów ${ }^{9}$. W związku z powyższym zadaniem policjantów municypalnych jest zapewnienie spokoju oraz porządku w miejscach publicznych, prowadzenie dochodzeń administracyjnych oraz czuwanie nad przestrzeganiem zasad handlu lokalnego.

System brytyjskiej Policji do 1964 r. stanowi typowy przykład decentralistycznego modelu systemu ochrony porządku i bezpieczeństwa publicznego. Obowiązujący model rekrutacji i szkolenia brytyjskich funkcjonariuszy w praktyce jest mocno zdecentralizowany. Każdy

\footnotetext{
${ }^{4}$ Komórki to wydziały: do walki z przestępczością narkotykową, samochodową, do ochrony placówek dyplomatycznych, do zwalczania przestępczości pseudokibiców, do walki z terrorem kryminalnym i zabójstw, wydział realizacji.

${ }^{5}$ Funkcjonuje w niektórych krajach jako instytucja powołana w celu utrzymywania porządku publicznego oraz bezpieczeństwa ludzi. Podlega lokalnemu samorządowi, a nie władzy centralnej.

${ }^{6}$ J. Czapska, J. Wójcikiewicz, Policja w społeczeństwie obywatelskim, Zakamycze 1999, s. 34.

${ }^{7}$ Od 1 stycznia 2009 r. podlega Ministerstwu Spraw Wewnętrznych..

${ }^{8}$ Syndyk gminny, sekretarz i skarbnik.

${ }^{9}$ J. Czapska, J. Wójcikiewicz, op. cit., s. 24-24.
} 
policjant, który wkracza w szeregi Policji, staje się obrońcą praw obywatelskich, służąc również koronie brytyjskiej - Królowej - a nie samemu państwu ${ }^{10}$.

\section{WPLYW ZIDENTYFIKOWANYCH ZAGROŻEŃ WYSTĘPUJĄCYCH W PRZESTRZENI WIELKICH MIAST NA KSZTALT STRUKTURY ORGANIZACYJNEJ KOMEND POLICJI}

W trakcie przeprowadzonych badań naukowych, w wybranych komendach Policji na terenie aglomeracji warszawskiej oraz trójmiejskiej, ustalono wpływ, jaki miały zagrożenia, które są identyfikowane w wielkich miastach, na kształt struktury organizacyjnej w tych komendach. $\mathrm{Na}$ samym początku jednak, przed przedstawieniem wyników badań, należy odnieść się do praktyki przyjętej w jednostkach Policji dotyczącej zmian strukturalno-etatowych. Podkreślenia wymaga fakt, iż w celu dokonywania zmian w strukturze komend miejskich oraz powiatowych niezbędna jest zgoda właściwego miejscowo komendanta wojewódzkiego Policji. Komendanci zobowiązani są do sporządzenia stosownego wniosku, który zawiera opis i zakres planowanych zmian, oraz jego uzasadnienia. Zazwyczaj wnioski dotyczyły powoływania nowych komórek organizacyjnych, ich przekształcenia bądź likwidacji, a także zwiększenia liczby etatów. Po uzyskaniu zgody, każda zmiana strukturalno-etatowa musiała zostać uwzględniona w „Regulaminie organizacyjnym" danej komendy, który określa:

- strukturę oraz zakresy działań poszczególnych komórek organizacyjnych,

- tryb kierowania komendami, komisariatami,

- szczegółowe zadania poszczególnych komórek organizacyjnych,

- zasady współdziałania podległych jednostek organizacyjnych.

Akty prawa wewnętrznego sankcjonujące zmiany organizacyjne, które wprowadzają wszystkie zmiany strukturalno-etatowe w jednostkach Policji, określamy jako rozkazy organizacyjne. Rozkazy mogą być wydawane przez kierowników jednostek wszystkich szczebli, aż do komendanta miejskiego (powiatowego) Policji ${ }^{11}$.

Stanowisko komendantów Policji na temat wpływu zagrożeń na kształt struktury organizacyjnej zawierają odpowiedzi na pytanie $1 \mathrm{z}$ kwestionariusza wywiadu, które brzmiało: „Czy liczba oraz charakter występujących zagrożeń wpływa na kształt struktury organizacyjnej w kierowanej przez Panią/Pana jednostki?” (do wyboru były odpowiedzi „tak” i „nie), oraz pytanie uzupełniające: „Jeżeli tak, to proszę o charakterystykę tego oddziaływania, ewentualnie o podanie przykładów”. Jak można zauważyć, zdania są podzielone. W 5 jednostkach na 7 struktura organizacyjna jednostek Policji była dostosowana do zagrożeń występujących na podległym terenie. Utworzono nowe

\footnotetext{
${ }^{10}$ I. Budzyńska, Modele systemów policyjnych oraz zmiany w organizacji policji w wybranych państwach, Kancelaria Sejmu Biuro Studiów i Ekspertyz Wydziału Analiz Ekonomicznych i Społecznych, Raport 185, grudzień 2000, s. 2-3.

${ }^{11}$ Obwieszczenie Komendanta Głównego Policji z 25 czerwca 2013 r. w sprawie ogłoszenia jednolitego tekstu zarządzenia komendanta głównego Policji w sprawie szczegółowych zasad organizacji i zakresu działania komend, komisariatów i innych jednostek organizacyjnych Policji (Dz. Urz. KGP poz. 50.).
} 
komórki organizacyjne lub zwiększono etaty. Z informacji uzyskanych w wywiadach od komendantów Policji można wywnioskować, iż zidentyfikowane zagrożenia występujące na terenie działania każdej z wybranych komend Policji mają bezpośredni wpływ na kształt struktury organizacyjnej poszczególnych komórek i jednostek organizacyjnych tychże komend. Wpływają także bezpośrednio na stany etatowe tych komórek oraz jednostek organizacyjnych. Warto dodać, że o przydziałach etatów, bądź o ich zmniejszeniu dla danej komendy Policji, decydują właściwi komendanci wojewódzcy Policji. Odpowiedzi na powyższe pytanie zawiera tabela nr 1 .

\begin{tabular}{|c|c|c|}
\hline Respondent & Pyt. 1 & Pytanie 2 \\
\hline $\begin{array}{l}\text { Komendant Stołeczny } \\
\text { Policji w Warszawie }\end{array}$ & TAK & $\begin{array}{l}\text { Struktura organizacyjna komendy uwzględnia potrzeby właściwej realizacji na- } \\
\text { kładanych na Policję zadań, a także jest dostosowana do liczby i charakteru wy- } \\
\text { stępujących zagrożeń. Odbywa się to jednak w ramach przydzielonych jedno- } \\
\text { stce etatów. Zmiana struktur odbywa się tym samym poprzez przesunięcia eta- } \\
\text { towe, a nie tworzenie nowych stanowisk. }\end{array}$ \\
\hline $\begin{array}{l}\text { Zastępca Komendanta } \\
\text { Rejonowego Policji } \\
\text { Warszawa IV }\end{array}$ & TAK & $\begin{array}{l}\text { Największym obecnym problemem, z którym się borykamy w Naszej Jedno- } \\
\text { stce, jest duża ilość wakatów oraz absencji osobowej, co z kolei przenosi się na } \\
\text { ponadnormatywne obciążenie obowiązkami oraz prowadzonymi sprawami } \\
\text { przez pozostałych funkcjonariuszy, jak i pozostałych pracowników Policji. }\end{array}$ \\
\hline $\begin{array}{l}\text { Komendant Rejonowy } \\
\text { Policji Warszawa V }\end{array}$ & TAK & $\begin{array}{l}\text { W związku z notowanym w ostatnich latach wzrostem liczby przestępstw z wy- } \\
\text { korzystaniem Internetu zwiększono o } 5 \text { liczbę etatów policyjnych w komórce } \\
\text { odpowiedzialnej za realizację tych zadań. Obecnie trwają kolejne prace dosto- } \\
\text { sowujące strukturę organizacyjną tej komórki do aktualnych potrzeb w aspekcie } \\
\text { sprawnej reakcji na stwierdzane zagrożenia. }\end{array}$ \\
\hline $\begin{array}{l}\text { Zastępca Komendanta } \\
\text { Komisariatu Policji } \\
\text { Warszawa Ursynów }\end{array}$ & NIE & - \\
\hline $\begin{array}{l}\text { I Zastępca Komen- } \\
\text { danta Miejskiego } \\
\text { Policji w Gdańsku }\end{array}$ & TAK & $\begin{array}{l}\text { Struktura przestępczości się zmienia. Struktura organizacyjna jednostki nie była } \\
\text { zmieniana pomimo, że przez wiele lat przestępczość w naszym mieście, jak } \\
\text { i z pewnością w innych większych aglomeracjach, zmieniała swoją charaktery- } \\
\text { stykę. W jednostce dochodzi do wewnętrznych kroków zmierzających do rea- } \\
\text { gowania na nasilone występowanie danego typu przestępczości lub zagrożen,, } \\
\text { np. poprzez delegowanie między Wydziałami policjantów, aby wesprzeć tę ko- } \\
\text { mórkę, która w danym okresie wymagała wsparcia. Takim przykładem było np. } \\
\text { zwiększenie liczby wakatów w pionie gospodarczym, w związku ze zwięk- } \\
\text { szoną liczbą przestępstw Internetowych - cyberprzestępczość. }\end{array}$ \\
\hline $\begin{array}{l}\text { Komendant Komisa- } \\
\text { riatu Policji II w Gdań- } \\
\text { sku }\end{array}$ & NIE & - \\
\hline $\begin{array}{l}\text { Komendant Komisa- } \\
\text { riatu Policji III } \\
\text { w Gdańsku }\end{array}$ & TAK & $\begin{array}{l}\text { Rozwija się przestępczość gospodarcza i w związku z tym, w mojej jednostce } \\
\text { utworzono Referat do Walki z Przestępczością Gospodarczą. }\end{array}$ \\
\hline
\end{tabular}

Tabela 1. Wpływ zagrożeń na etaty komend miejskich - opinia komendantów Policji Źródło: Opracowanie własne na podstawie wyników badań. 
Opinię komendantów Policji na temat większego zagrożenia wzrostem przestępczości i rozwojem środowisk przestępczych w dużych aglomeracjach miejskich zawierają odpowiedzi na pytanie pierwsze kwestionariusza wywiadu, które brzmiało: „Czy Pani/Pana zdaniem duże aglomeracje miejskie są bardziej zagrożone wzrostem przestępczości i rozwojem środowisk przestępczych, niż małe ośrodki miejskie” - do wyboru były odpowiedzi „tak” lub „nie” - oraz pytanie uzupełniające: ,Jeśli tak, to dlaczego? Jeśli nie, to dlaczego?”. Odpowiedzi na powyższe pytanie zawiera tabela nr 2.

\begin{tabular}{|c|c|c|}
\hline Respondent & Pyt. 1 & Pytanie 2 \\
\hline $\begin{array}{l}\text { Komendant Stołeczny } \\
\text { Policji w Warszawie }\end{array}$ & TAK & $\begin{array}{l}\text { Duże aglomeracje miejskie są bardziej zagrożone wzrostem przestęp- } \\
\text { czości i rozwojem środowisk przestępczych, niż małe ośrodki miejskie. } \\
\text { Głównymi przyczynami takiego stanu rzeczy są: } \\
\text { - duże skupiska ludzi, } \\
\text { - } \text { anonimowość wśród mieszkańców, } \\
\text { - napływowość, zarówno osób poszukujących pracy, pracujących, } \\
\quad \text { jak i turystów. }\end{array}$ \\
\hline $\begin{array}{l}\text { Zastępca Komendanta } \\
\text { Rejonowego Policji } \\
\text { Warszawa IV }\end{array}$ & TAK & $\begin{array}{l}\text { Duże aglomeracje miejskie np. Warszawa są bardziej zagrożone prze- } \\
\text { stępczością głównie zorganizowaną o charakterze zbrojnym. W głów- } \\
\text { nej mierze związane jest to z napływem obcokrajowców do tych aglo- } \\
\text { meracji oraz szybkim gromadzeniem środków płatniczych, jak i dóbr } \\
\text { dostępnych w dużych miastach celem korzystania z nich. }\end{array}$ \\
\hline $\begin{array}{l}\text { Komendant Rejonowy } \\
\text { Policji Warszawa V }\end{array}$ & TAK & $\begin{array}{l}\text { W mojej ocenie, duże aglomeracje miejskie, są bardziej zagrożone } \\
\text { wzrostem przestępczości i rozwojem środowisk przestępczych. Wielkie } \\
\text { skupiska ludności, zwarta infrastruktura mieszkaniowa, handlowa } \\
\text { i usługowa, przy występującej jednocześnie dużej anonimowości i rota- } \\
\text { cji ludności, są warunkami o wiele korzystniejszymi dla działalności } \\
\text { przestępczej niż mniejsze ośrodki. }\end{array}$ \\
\hline $\begin{array}{l}\text { Zastępca Komendanta } \\
\text { Komisariatu Policji } \\
\text { Warszawa Ursynów }\end{array}$ & TAK & $\begin{array}{l}\text { Duże aglomeracje miejskie są zdecydowanie bardziej zagrożone wzro- } \\
\text { stem przestępczości i rozwojem środowisk przestępczych niż małe } \\
\text { ośrodki miejskie. Wpływ na to ma przede wszystkim większa anonimo- } \\
\text { wość takich środowisk w dużych ośrodkach niż w małych, gdzie ta ano- } \\
\text { nimowość jest zdecydowanie mniejsza i przez to bardziej narażona } \\
\text { na dekonspiracje prowadzonej działalności przestępczej. W związku } \\
\text { z tym w dużych miastach grupy przestępcze mogą się zdecydowanie } \\
\text { bardziej rozwijać. }\end{array}$ \\
\hline $\begin{array}{l}\text { I Zastępca Komendanta } \\
\text { Miejskiego Policji } \\
\text { w Gdańsku }\end{array}$ & TAK & $\begin{array}{l}\text { Duże aglomeracje miejskie są bardziej zagrożone wzrostem przestęp- } \\
\text { czości o różnym charakterze. Głównie związane jest to ze skupiskiem } \\
\text { osób w głównej mierze obcokrajowców i osób przejezdnych. Ponadto } \\
\text { w dużych aglomeracjach jest większa anonimowość wśród jej miesz- } \\
\text { kańców, przez co trudniej jest dotrzeć do środowisk przestępczych, } \\
\text { a przy tym środowiska przestępcze mają większe możliwości swojej } \\
\text { działalności. }\end{array}$ \\
\hline $\begin{array}{l}\text { Komendant Komisa- } \\
\text { riatu Policji II } \\
\text { w Gdańsku }\end{array}$ & NIE & $\begin{array}{l}\text { Problemy wzrostu przestępczości oraz rozwój środowisk przestępczych } \\
\text { w mojej opinii należy rozpatrywać osobno. Samo zagrożenie przestęp- } \\
\text { czością w dużych aglomeracjach miejskich może wynikać między in- } \\
\text { nymi z samej gęstości zaludnienia, bogacenia się społeczeństwa wiel- } \\
\text { komiejskiego. W aglomeracji gdańskiej, obserwuję na przestrzeni ostat- } \\
\text { nich lat, znaczny spadek przestępczości z kategorii najpoważniejszych } \\
\text { (zabójstwa, zgwałcenia, rozboje itp.), jak i tych drobniejszych }\end{array}$ \\
\hline
\end{tabular}




\begin{tabular}{|c|c|c|}
\hline & & $\begin{array}{l}\text { (włamania, kradzieże). Spadki takie wynikają - w mojej opinii - ze } \\
\text { zmiany charakteru przestępczości na cyberprzestępczośc, wyjazdu pew- } \\
\text { nej grupy społecznej za granicę „w celach zarobkowych”, znaczną in- } \\
\text { filtrację środowisk przestępczych, działanie na terenach dużych aglome- } \\
\text { racji miejskich funkcjonariuszy z różnych jednostek organizacyjnych } \\
\text { Policji (dla przykładu na terenie Gdańska ścierają się działania np. funk- } \\
\text { cjonariuszy z Komendy Wojewódzkiej Policji, Komendy Miejskiej, ko- } \\
\text { misariatów, a nawet CBŚP). Takie nagromadzenie sił powoduje rów- } \\
\text { nież, że sam rozwój środowisk przestępczych w dużych aglomeracjach } \\
\text { miejskich w chwili obecnej jest utrudniony. Dowodem na to są infor- } \\
\text { macje przekazywane przez media na temat rozbijanych na bieżąco } \\
\text { „raczkujących” grup przestępczych. W mojej opinii prywatnie jako } \\
\text { mieszkańca terenów wiejskich (pod Gdańskiem) w chwili obecnej to } \\
\text { właśnie poza dużymi aglomeracjami może wystąpić większe zagroże- } \\
\text { nie przestępczością i rozwojem środowisk przestępczych. }\end{array}$ \\
\hline $\begin{array}{l}\text { Komendant Komisa- } \\
\text { riatu Policji III } \\
\text { w Gdańsku }\end{array}$ & NIE & $\begin{array}{l}\text { W mojej ocenie tendencja jest odwrotna, to w dużych aglomeracjach } \\
\text { przestępczość „pospolita” taka jak kradzieże, włamania, rozboje jest } \\
\text { znikoma. Tych zdarzeń jest zdecydowanie mniej. Powodem tego może } \\
\text { być „dojrzałóśc” społeczeństwa, chęć nauki i poboru pracy, by dążyć do } \\
\text { nabycia dóbr materialnych. Zawsze znajdzie się ktoś, kto będzie doko- } \\
\text { nywał kradzieży, ale na przełomie } 10 \text { lat ta przestępczość zmalała, } \\
\text { w mojej ocenie, o połowę. Przestępczość rozwija się w cyberprzestrzeni } \\
\text { i ukierunkowana została na oszustwa i wyłudzenia (wzrost). }\end{array}$ \\
\hline
\end{tabular}

Tabela 2. Zagrożenie wzrostem przestępczości i rozwojem środowisk przestępczych, a miejsce zamieszkania - ocena komendantów Policji

Źródło: Opracowanie własne na podstawie wyników badań.

Do rodzajów zagrożeń uciążliwych ze sfery bezpieczeństwa i porządku publicznego na podległym terenie odnieśli się komendanci Policji w odpowiedziach na pytanie 3, które brzmiało: „Jakie rodzaje zagrożeń uciążliwych ze sfery bezpieczeństwa oraz porządku publicznego obserwuje Pani/Pan najczęściej na terenie podległym w kierowanej przez Panią/Pana jednostce? Które z wymienionych zagrożeń stanowią lub stanowiły kluczowy problem dla mieszkańców?”. Wszystkie odpowiedzi przedstawiono w tabeli nr 3.

\section{Komendant Stołeczny Policji w Warszawie}

Wśród najbardziej uciążliwych dla mieszkańców zagrożeń wymienić należy kradzieże (w tym także pojazdów). Natomiast jeżeli chodzi o zagrożenia, stanowiące kluczowy problem dla mieszkańców, to należy posiłkować się $\mathrm{w}$ tej kwestii przekazywanymi od nich sygnałami. Zgodnie z informacjami od mieszkańców przekazywanymi za pośrednictwem Krajowej Mapy Zagrożeń Bezpieczeństwa, najbardziej uciążliwe dla mieszkańców jest:

- nieprawidłowe parkowanie (w kontekście osiedli mieszkaniowych - zastawiania chodników niszczenia terenów zielonych) - 31,1\% wszystkich zgłoszeń,

- przekraczanie dozwolonej prędkości na drogach publicznych i w strefach zamieszkania - $21,5 \%$ wszystkich zgłoszeń,

- spożywanie alkoholu w miejscach objętych zakazem - 13,7\% wszystkich zgłoszeń.

\section{Zastępca Komendanta Rejonowego Policji Warszawa IV}

W dzielnicy Woli oraz Bemowa $\mathrm{w}$ Warszawie największym zagrożeniem są: kradzież samochodów osobowych, kradzież z włamaniem do mieszkań i pomieszczeń gospodarczych oraz bójki i pobicia. Natomiast liczba „pospolitych” kradzieży pozostaje na tym samym poziomie. Liczba popełnionych przestępstw wynika 
z rozmaitych czynników, np. zamożności społeczeństwa, nagłych zmian społecznych, od oświetlenia ulic, do braku monitoringu.

\section{Komendant Rejonowy Policji Warszawa V}

Do najliczniejszych zdarzeń z kategorii uciążliwych społecznie należy zaliczyć: kradzieże, włamania oraz uszkodzenia mienia. W kategorii uszkodzeń mienia znaczna część tych zagrożeń wynika z braku miejsc parkingowych oraz bardzo dużej liczby pojazdów. Jednak obawy mieszkańców, oprócz problemów z parkowaniem, czy bezpieczeństwem w ruchu drogowym, często skierowane są na zakłócenia ciszy nocnej, wybryki chuligańskie i osoby nietrzeźwe - szczególnie w porze letniej.

\section{Zastępca Komendanta Komisariatu Policji Warszawa Ursynów}

Jednym z największych zagrożeń uciążliwych ze sfery bezpieczeństwa oraz porządku publicznego na podległym terenie jest niewątpliwie przestępczość narkotykowa, która ma duży wpływ na bezpieczeństwo oraz porządek publiczny. Osoby uzależnione szukają środków pieniężnych na narkotyki, poprzez dokonywanie kradzieży, kradzieży z włamaniem oraz rozbojów.

\section{Zastępca Komendanta Miejskiego Policji w Gdańsku}

Najbardziej uciążliwe dla mieszkańców zagrożenia to imprezy masowe, zgromadzenia, pikiety i związane z tym „wycięcie” ulic. W tym przypadku nie sposób nie wspomnieć o zagrożeniach uciążliwych wynikających $\mathrm{z}$ agresywnych zachowań pseudokibiców.

\section{Komendant Komisariatu Policji II w Gdańsku}

Dla mieszkańców zamieszkujących teren podległy w kierowanej jednostce w szczególności zaliczyć należy problemy z nieprawidłowym parkowaniem pojazdów (utrudnienia związane z brakiem odpowiedniej ilości takich miejsc), spożywaniem alkoholu w miejscach do tego nieprzewidzianych oraz zakłócenia ciszy nocnej przez działające lokale.

Komendant Komisariatu Policji III w Gdańsku

Do najbardziej uciążliwych dla społeczeństwa należą kradzieże dokumentów (najczęściej są to zagubienia, ale ludzie wolą tłumaczyć się, że dokonano kradzieży, nie dopuszczając myśli, że zgubił), uszkodzenia pojazdów.

Tabela 3. Rodzaje zagrożeń uciążliwych ze sfery bezpieczeństwa oraz porządku publicznego występujących na podległym terenie - opinia komendantów Policji

Źródło: Opracowanie własne na podstawie wyników badań.

Zdanie komendantów Policji na temat przyjętych działań w celu zwiększenia bezpieczeństwa w dużych aglomeracjach miejskich oddaje odpowiedź na pytanie: „Jakie działania podjęłaby/podjąłby Pani/Pan, aby zwiększyć bezpieczeństwo w dużych aglomeracjach miejskich?”. Zwiększenie ilości policjantów pełniących służbę w dużych aglomeracjach jest gwarantem większego bezpieczeństwa. Zwiększenie ilości etatów oraz przede wszystkim ich zapełnienie daje większe możliwości organizowania wyspecjalizowanych zespołów zajmujących się danym typem przestępczości lub zapobieganiem występujących zagrożeń. Ważną kwestią wydaje się tu rozbudowany system monitoringu, lepsze wyposażenie funkcjonariuszy, a także współpraca z innymi służbami porządkowymi. Odpowiedzi przedstawia tabela $\mathrm{nr} 4$.

\section{Komendant Stoleczny Policji w Warszawie}

W celu poprawy bezpieczeństwa $w$ dużych aglomeracjach właściwym kierunkiem byłoby stworzenie rozwiązań umożliwiających dostosowanie liczby etatów do faktycznych potrzeb jednostki. Istotną rolą tego rozwiązania jest przywrócenie służb patrolowych. Obecnie liczba zadań i zgłaszanych interwencji powoduje, że załogi kierowane do służby, kosztem patrolowania miejsc niebezpiecznych, reagują na zgłaszane interwencje oraz zabezpieczają miejsca zdarzeń. Ogromny wpływ na poprawę bezpieczeństwa ma także monitoring miejski i jego profesjonalna obsługa, gdyż tylko taka pozwala zapobiegać przestępstwom i wykroczeniom, a w ostateczności zatrzymaniu sprawców na gorącym uczynku ich popełnienia. 
Przede wszystkim dążyłbym, poprzez zmianę struktury Policji, do uzupełnienia wakatów w komendach oraz komisariatach. Zwróciłbym szczególną uwagę na współpracę z przedstawicielami urzędów państwowych, Straży Miejskiej, Żandarmerii Wojskowej oraz przedstawicieli Spółdzielni Mieszkaniowych oraz Wspólnot Mieszkaniowych.

\section{Komendant Rejonowy Policji Warszawa V}

Należy zwiększyć nacisk, nie tylko w szkołach, na kształtowanie postaw obywatelskich. Rozbudowa systemu monitoringu. Odpowiednie nasycenie poszczególnych rejonów patrolami policji.

\section{Zastępca Komendanta Komisariatu Policji Warszawa Ursynów}

Zwiększenie etatów policyjnych w jednostkach. Doposażenie funkcjonariuszy w nowoczesne środki techniczne. Zwiększenie (znaczne) uposażenia funkcjonariuszy pracujących w dużych aglomeracjach, co spowoduje zatrzymanie odpływu policjantów do mniejszych jednostek.

\section{Zastępca Komendanta Miejskiego Policji w Gdańsku}

Jesteśmy w trakcie realizacji projektu, który ma na celu pozyskanie i rozwój technologii „Nowoczesna technologia i innowacja rozwiązania w zakresie wykrywania, zwalczania i neutralizacji zagrożeń”. Główną motywacją dla powstania narzędzia jest obróbka zabezpieczonego materiału video oraz sygnału video, pozwalającego na szybszą i sprawną identyfikację osób będących w zainteresowaniu Policji, szybkim wykrywaniem w dostarczonym materiale czynów zabronionych. Wykorzystanie narzędzia w pracy funkcjonariuszy poprzez szybszą i skuteczniejszą analizę materiału video, będzie miało bezpośredni wpływ na wzrost poziomu szeroko rozumianego bezpieczeństwa i obronności państwa, m. in. poprzez szybszą identyfikację i zatrzymywanie przestępców, a także przyczyni się do wzrostu wykrywalności prowadzonych przez Policję postępowań przygotowawczych i spraw operacyjnych dzięki możliwości dokładnej analizy materiału video.

\section{Komendant Komisariatu Policji II w Gdańsku}

W mojej opinii dla dużych aglomeracji miejskich konieczne jest, oprócz zabezpieczenia osobowego, stworzenie zintegrowanych zabezpieczeń technicznych. Musi to jednak przebiegać w ten sposób, że koordynacja następuje z jednego miejsca, przekazywane informacje muszą dochodzić do konkretnych służb, musi nastąpić skrócenie drogi decyzyjnej do minimum. Odnośnie zabezpieczenia osobowego służby muszą posiadać pełna obsadę kadrową (co uzależnione jest od rynku pracy).

\section{Komendant Komisariatu Policji III w Gdańsku}

Nowelizacja kodeksu postępowania karnego, zminimalizowanie biurokracji. Spowodowałoby to zwiększenie ilości policjantów w przestrzeni publicznej.

Tabela 4. Działania w celu zwiększenia bezpieczeństwa w dużych aglomeracjach miejskich - opinia komendantów Policji

Źródło: Opracowanie własne na podstawie wyników badań.

W odniesieniu do działań, jakie należy podjąć w celu usprawnienia funkcjonowania Policji $\mathrm{w}$ walce $\mathrm{z}$ zagrożeniami, komendanci wypowiedzieli się wyrażając swoje opinie w odpowiedziach na pytanie 7 z kwestionariusza wywiadu. Pytanie to brzmiało: „Jakie działania należy podjąć, w Pani/Pana opinii, na terenie dużych aglomeracji miejskich, by usprawnić funkcjonowanie Policji w walce z zagrożeniami?”. Odpowiedzi komendantów przedstawiono w tabeli nr 5.

\section{Komendant Stoleczny Policji w Warszawie}

W celu usprawnienia funkcjonowania Policji w walce z zagrożeniami należy przede wszystkim ustabilizować sytuację kadrową i wprowadzić rozwiązania zapewniające przejrzystość rekrutacji i przyjęć oraz ścieżki awansu. Dodatkowo konieczne jest wprowadzenie rozwiązań zapobiegających odejściom doświadczonych policjantów poprzez gratyfikację za pracę, mimo uzyskania uprawnień emerytalnych. Konieczne są także regulacje zabezpieczające instytucję przed odejściami z Policji osób zatrudnianych w trakcie szkoleń lub bezpośrednio po ich zakończeniu. Skutkować one powinny zwrotem kosztów rekrutacji i szkolenia. Kolejnym bardzo ważnym elementem jest dalsze budowanie zaufania do instytucji ścigających sprawców przestępstw i wykroczeń, 
nie tylko Policji, ale także Prokuratury i Sądu. Dodatkowo jednostki powinny zostać wzmocnione etatowo przynajmniej w ramach struktur RD i OPP/SPP. Liczba realizowanych zabezpieczeń powinna skutkować wzmocnieniem Oddziałów Prewencji Policji, a dynamiczny wzrost liczby użytkowników dróg wzmocnieniem komórek odpowiedzialnych za bezpieczeństwo w ruchu drogowym.

\section{Zastępca Komendanta Rejonowego Policji Warszawa IV}

Zwiększyć nacisk oraz usankcjonować kwestie obowiązkowego monitoringu u osób prowadzących działalności gospodarcze, spółdzielnie, wspólnoty mieszkaniowe. Przede wszystkim zwiększyć do maksimum sieć monitoringu miejskiego na dzielnicach, osiedlach oraz drogach dojazdowych.

\section{Komendant Rejonowy Policji Warszawa V}

Należy przede wszystkim mieć na uwadze, że bezpieczeństwo publiczne wiąże się z ponoszeniem znaczących kosztów. I co do tego nikt nie ma wątpliwości. Stoimy tylko przed dylematem, czy będą to koszty budżetowe, czy w innym przypadku będą to koszty ponoszone przez społeczeństwo. Należy zatem usprawniać instytucje państwowe związane ze sferą bezpieczeństwa, poprzez racjonalizację działań biurokratycznych na rzecz efektywności i skuteczności realizacji zadań podstawowych. Ponadto niezbędne wydaje się dostosowanie struktur i etatów policji do lokalnych potrzeb oraz zapewnienie finansowania gwarantującego właściwe wyposażenie oraz dobór i wyszkolenie odpowiednich kadr.

\section{Zastępca Komendanta Komisariatu Policji Warszawa Ursynów}

Zwiększenie ilości patroli prewencyjnych działających $\mathrm{w}$ terenie, ale jednocześnie nierealizujących interwencji zleconych przez dyżurnych. Spowoduje to koncentrację tych policjantów na działaniach prewencyjnych, ale również na eliminacje zagrożenia. Zwiększenie ilości policjantów pracujących po cywilnemu w terenie, ale koncentrujących się tylko na zatrzymywaniu sprawców przestępstw.

\section{Zastępca Komendanta Miejskiego Policji w Gdańsku}

Program, pozwalający na szybszą i sprawną identyfikację osób będących w zainteresowaniu Policji, szybkim wykrywaniem w dostarczonym materiale czynów zabronionych.

\section{Komendant Komisariatu Policji II w Gdańsku}

Należy dążyć do większej integracji wszystkich służb porządkowych działających na terenie aglomeracji miejskich.

\section{Komendant Komisariatu Policji III w Gdańsku}

Zwiększenie ilości funkcjonariuszy Policji, monitoring miejski.

Tabela 5. Propozycje działań w celu usprawnienia funkcjonowania Policji w walce z zagrożeniami - opinia komendantów Policji

Źródło: Opracowanie własne na podstawie wyników badań.

Bardzo ważnym pytaniem jakie zadano komendantom Policji było: „Czy może Pani/Pan wskazać, jakie skuteczne i specyficzne, a zarazem odmienne od typowych rozwiązań organizacyjnych w funkcjonowaniu Policji na podległym terenie, można by było wdrożyć w walce z zagrożeniami?’. Odpowiedzi ankietowanych komendantów Policji bardzo się różniły. Każdy miał inne pomysły na temat rozwiązań organizacyjnych w funkcjonowaniu Policji, co przedstawiono w tabeli nr 6.

\section{Komendant Stoleczny Policji w Warszawie}

W celu poprawy stanu bezpieczeństwa w ruchu drogowym, a w szczególności przeciwdziałaniu agresywnym i szczególnie niebezpiecznym zachowaniom powołany został Zespół pod nazwą „SPEED”. W skład powyższego zespołu wchodzą policjanci Wydziału Ruchu Drogowego oraz Wydziału Kryminalnego i Wydziału dw. z Cyberprzestępczością. Do składu zespołu mogą zostać również powołani policjanci innych komórek i jednostek podległych Komendantowi Stołecznemu Policji. Komenda wyposażona jest także w dwa pojazdy dostosowane do przyjęć interesantów zwane Mobilnymi Posterunkami Policji. Głównym założeniem „Mobilnego Posterunku Policji” jest bezpośrednie dotarcie policyjnych specjalistów z różnych dziedzin (prewencji kryminalnej, dochodzeniowo-śledczej, dzielnicowych), do mieszkańców, szczególnie do miejsc i osiedli, pozbawionych bezpośrednio w swoim otoczeniu, jednostek Policji. 
„MPP” wykorzystywany może być także przy obsłudze poważnych zdarzeń, a w szczególności w przypadkach konieczności wykonania czynności niecierpiących zwłoki (przesłuchanie kilkudziesięciu świadków lub pokrzywdzonych bez konieczności ich wzywania do jednostki, np. mieszkańców bloku lub pracowników zakładu pracy), a także jako mini sala odpraw policjanta przed podejmowanymi działaniami na wyznaczonym obszarze. Mobilny Posterunek Policji spełniać może rolę:

- Mobilnej jednostki Policji,

- Punktu przyjęć interesantów,

- Pokoju przesłuchań,

- Sali odpraw,

- Punktu rekrutacyjnego.

\section{Zastępca Komendanta Rejonowego Policji Warszawa IV}

Na podstawie sprawdzonych, skutecznych rozwiązań organizacyjnych w funkcjonowaniu Policji na przykładzie, sprawdzonych już w innych państwach takich jak: Szkocja, Anglia, Holandia, Niemcy, Francja, jest bezwzględne wprowadzenie obowiązkowego instalowania monitoringu oraz współpraca w zwalczaniu np. procederu narkotykowego, z takimi instytucjami jak: Sanepid, Urząd Skarbowy, Urząd Miasta, szpitale i inne instytucje, które mają ustawowy wpływ na bezwzględne zlikwidowanie danego procederu zaistniałego w poszczególnych dzielnicach, osiedlach, terenach dużych aglomeracji.

\section{Komendant Rejonowy Policji Warszawa V}

Wszystkie propozycje $\mathrm{w}$ tym zakresie związane są $\mathrm{z}$ dostosowaniem obsady etatowej do występujących potrzeb. Wynika to w szczególności z bardzo szerokiego spektrum zadań, za które odpowiedzialna jest Policja.

\section{Zastępca Komendanta Komisariatu Policji Warszawa Ursynów}

- Stosowanie środka zapobiegawczego w postaci dozoru przez Policję (dozór stosuje prokurator lub sąd), wymagana zmiana ustawodawcza;

- Wykorzystywanie bezpośrednio przez jednostki Policji środków technicznych, które w chwili obecnej są wykorzystywane tylko i wyłącznie poprzez zlecenie realizacji specjalistycznemu wydziałowi (urządzenia do lokalizacji telefonów, drony, urządzenia gps);

- Wymiana pomiędzy jednostkami policjantów pracujących po cywilnemu w terenie, większa anonimowość wśród środowisk przestępczych.

\section{Zastępca Komendanta Miejskiego Policji w Gdańsku}

Warto zastanowić się nad tym, aby służba kryminalna podlegała bezpośrednio pod KGP, zaś prewencja powinna współpracować bardziej z samorządami.

\section{Komendant Komisariatu Policji II w Gdańsku}

W ramach monitoringu wizyjnego stworzenie jednego centrum dowodzenia służbami wspomożonego przez elektroniczny system identyfikacji twarzy.

Komendant Komisariatu Policji III w Gdańsku

Moje pomysły dotyczą jedynie zmian globalnych, bo to one będą mogły mieć wpływ na zmianę lokalną.

Tabela 6. Propozycje rozwiązań organizacyjnych w funkcjonowaniu Policji w walce z zagrożeniami - opinia komendantów Policji

Źródło: Opracowanie własne na podstawie wyników badań

\section{OCENA MOŻLIWOŚCI PRZENIESIENIA ROZWIĄZAŃ M. ST. WARSZAWY DO INNYCH AGLOMERACJI}

Badania empiryczne przeprowadzone wśród funkcjonariuszy Policji pozwoliły na ustalenie opinii badanych odnośnie potrzeby zmian w obecnie obowiązującym systemie bezpieczeństwa publicznego. Na pytanie jednokrotnego wyboru o treści: „Czy uważa Pan/Pani, że struktura organizacyjna Policji powinna być indywidualnie dopasowana do każdego województwa?” - 59\% ogółu respondentów stwierdziła, iż indywidualne dopasowanie struktury organizacyjnej Policji w każdym 
województwie byłoby dobrym rozwiązaniem. Ponad 1/3 badanych (35\%) jest odmiennego zdania, twierdząc, iż obowiązująca struktura organizacyjna Policji spełnia swoje zasadnicze funkcje w zakresie bezpieczeństwa. Szczegółowe wyniki przedstawiono na rysunku nr 1.

\section{Czy uważa Pan/Pani, że struktura organizacyjna Policji powinna być indywidualnie dopasowana do każdego województwa?}



Tak

$\square \mathrm{Nie}$

Nie mam zdania

Rysunek 1. Indywidualnie dopasowanie struktury organizacyjnej Policji w każdym województwie - ogół respondentów Źródło: Wyniki badań własnych.

W tej kwestii szczególnie istotna wydaje się opinia osób, zajmujących stanowiska kierownicze związane z realizacją i organizacją zadań na rzecz bezpieczeństwa i porządku publicznego $\mathrm{w}$ dużych aglomeracjach miejskich. W związku z powyższym podczas wywiadu z komendantami Policji zadano pytanie: „Czy uważa Pani/Pan, że struktura organizacyjna Policji powinna być indywidualnie dopasowana do każdej aglomeracji?”. Odpowiedzi komendantów Policji przedstawiono w tabeli nr 7.

\section{Komendant Stoleczny Policji w Warszawie}

Każda aglomeracja jest inna, z uwagi na jej wielkość, zaludnienie, położenie, lokalizację siedzib władz i urzędów państwowych i samorządowych, uprzemysłowienie, atrakcyjność turystyczną. Niesie to za sobą inne zagrożenia, jak również inne problemy społeczne. Tym samym struktura organizacyjna powinna być indywidualnie dopasowana do każdej aglomeracji.

\section{Zastępca Komendanta Rejonowego Policji Warszawa IV}

Tak - uważam, że struktura organizacyjna powinna być indywidualnie dopasowana do poszczególnych aglomeracji, co sprowadza się do przykładów innych państw tj.: Holandia, Szkocja, Anglia i inne.

\section{Komendant Rejonowy Policji Warszawa V}

Tak, w mojej ocenie, powinien być dostosowany do lokalnych uwarunkowań. Zarówno w zakresie struktur i naliczeń etatowych, jak i realizacji ustawowych zadań wychodzących naprzeciw oczekiwaniom społecznym.

\section{Zastępca Komendanta Komisariatu Policji Warszawa Ursynów}

Zdecydowanie tak.

\section{Zastępca Komendanta Miejskiego Policji w Gdańsku}

Tak, uważam, że struktura organizacyjna Policji powinna być indywidualnie i z osobna dopasowana do poszczególnych aglomeracji.

Komendant Komisariatu Policji II w Gdańsku

Zgadzam się z tą tezą, by struktury te dopasowywać indywidualnie do każdej aglomeracji. 


\begin{tabular}{|l|}
\hline \multicolumn{1}{|c|}{ Komendant Komisariatu Policji III w Gdańsku } \\
\hline $\begin{array}{l}\text { Tak. Uważam, że strukturę organizacyjną należałoby odwrócić. To my jako komendanci powinniśmy być gło- } \\
\text { sem przełożonych w sprawie potrzeb jednostek. }\end{array}$ \\
\hline
\end{tabular}

Tabela 7. Indywidualność dopasowania struktury organizacyjnej Policji do każdej aglomeracji - ocena komendantów Policji ${ }^{12}$

Źródło: Opracowanie własne na podstawie wyników badań.

Kolejne pytanie dotyczyło wprost oceny możliwości przeniesienia rozwiązań warszawskich do innych aglomeracji. Na pytanie jednokrotnego wyboru o treści: „Czy Pana/Pani zdaniem, możliwe jest przeniesienie rozwiązań funkcjonujących w stołecznej Policji do komend znajdujących się w innych dużych aglomeracjach w Polsce?” - ponad połowa, 54\% ogółu respondentów wskazało na odpowiedź „,raczej tak” i 9\% na „zdecydowanie tak”. Zatem 63\% wszystkich respondentów uważa, że możliwe jest przeniesienie rozwiązań funkcjonujących w stołecznej Policji do komend znajdujących się w innych dużych aglomeracjach w Polsce. 19\% wszystkich badanych nie widzi szans na przeniesienie takich rozwiązań. Aż 18\% funkcjonariuszy nie miało zdania na powyższy temat, co może świadczyć o braku znajomości dostępnych rozwiązań funkcjonujących w Warszawie. Wyniki przedstawia rysunek 2.

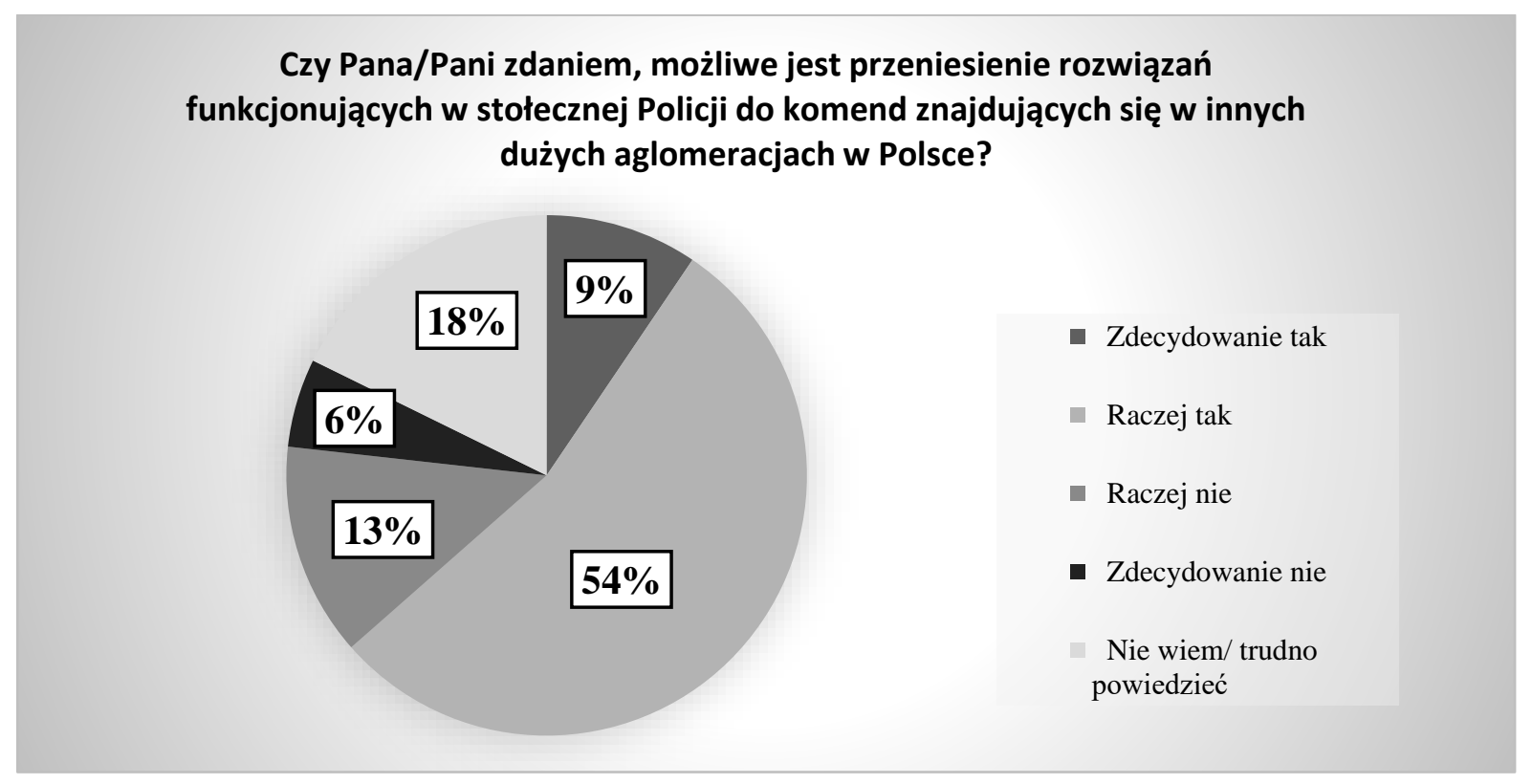

Rysunek 2. Istnienie możliwości przeniesienia rozwiązań stosowanych w stołecznej Policji do komend znajdujących się w innych dużych aglomeracjach Źródło: Wyniki badań własnych, dotyczące całej grupy respondentów.

Z dotychczasowych wyników badań można wyciągnąć pewne ogólne wnioski, a mianowicie: struktura organizacyjna Policji powinna być indywidualnie dopasowana do każdej aglomeracji oraz można spróbować przenieść rozwiązania funkcjonujące w stołecznej Policji do komend znajdujących się w innych dużych aglomeracjach w Polsce. Przyjęty jeden uniwersalny schemat organizacji Policji w Polsce i jej funkcjonowania, przez stosowanie określonych form oraz

${ }^{12}$ Opracowanie własne na podstawie wyników badań. 
metod, ogranicza w pewien sposób autonomię komendantów Policji w zapewnieniu bezpieczeństwa w wielkich miastach. Każda aglomeracja ma swoją specyfikę - wpływa na to ilość mieszkańców (zagęszczenie ludności), architektura (intensywność zabudowy) i infrastruktura miasta (drogi, szlaki kolejowe, węzły transportowe, lotnisko itp.), w tym infrastruktura krytyczna (systemy wodociągowe, kanalizacyjne, energetyczne, ciepłownicze, gazownicze, telekomunikacyjne i transportowe). Wzrost zachowań o charakterze przestępczym związany jest $\mathrm{z}$ aktywnością w wielkich aglomeracjach, w których dochodzi często do tworzenia się warstw marginesu społecznego. Wynikać to może przede wszystkim z tego, iż w Polsce dochodzi do ciągłej zmiany rynku pracy, wymagające coraz większej dynamiki w zakresie kreowania wizerunku oraz podnoszenia kwalifikacji służbowych ${ }^{13}$. W tym zakresie nie wolno zapominać o tym, że to właśnie duże aglomeracje miejskie są najczęstszymi celami ataków terrorystycznych i w tym zakresie bezwzględnie duże aglomeracje wymagają, aby system bezpieczeństwa był indywidualnie dopasowany. Po zakończeniu zimnej wojny w 1991 roku, w czasie której istniała realna groźba użycia broni atomowej przeciwko wielkim aglomeracjom miejskim, przyjęto nową doktrynę militarną. Jej założenie skupiało się na wzroście ryzyka użycia broni jądrowej przez ugrupowania terrorystyczne. Pozyskanie wspomnianej wyżej broni wiąże się głownie z działaniem zorganizowanej przestępczości, która w okresie zagrożeń terrorystycznych jest „niezauważalna”, ale nadal istnieje i działa ${ }^{14}$.

Rozwiązanie, jakie obecnie funkcjonuje w Warszawie, jest właściwe i powinno być przeniesione do innych aglomeracji. Zorganizowanie komend rejonowych nastąpiło przez wydzielenie przez komendanta stołecznego Policji z podległych jednostek Policji obiektów, wyposażenia, liczby wakatów oraz innych składników majątkowych. Analiza struktury organizacyjnej KSP w Warszawie wskazuje, iż jednostka ta oprócz typowych komórek, które powołane są do zwalczania zagrożeń funkcjonujących we wszystkich jednostkach Policji w Polsce, posiada w swojej strukturze nietypowe, specyficzne komórki. Ich celem jest zwalczanie zagrożeń ujawniających się przede wszystkim na terenie miasta Warszawy. Ponadto warto przypomnieć, że strukturę organizacyjną siedmiu komend rejonowych w Warszawie określono w regulaminach, odrębnie dla każdej z nich. Z analizy ich treści wynika, że struktura organizacyjna ułożona jest tak, żeby była dopasowana do zwalczania zagrożeń, jakie przeważają w Warszawie. Badania empiryczne przeprowadzone wśród funkcjonariuszy Policji w aglomeracji warszawskiej i trójmiejskiej wskazują, że możliwe jest przeniesienie rozwiązań istniejących w stołecznej Policji do innych dużych aglomeracji w Polsce.

\footnotetext{
${ }^{13}$ A. Łuczyszyn, T. Łuczyszyn, Miasta jako przestrzenie kumulacji przestępczości, [w:] B. Wiśniewska-Paź, J. Stelmach (red.), Bezpieczeństwo antyterrorystyczne budynków użyteczności publicznej. T. 3 Terroryzm, zamachy, sprawcy vs sposoby minimalizacji skutków, Toruń 2019, s. 210.

${ }^{14}$ A. Urban, Ksztattowanie bezpiecznych przestrzeni miejskich, [w:] W. Kustra, L. Smolak (red.), Bezpieczne miasta: wspótczesne zagrożenia i wyzwania, Warszawa 2013, s. 229.
} 


\section{KONCEPCJA SYSTEMU BEZPIECZEŃSTWA PUBLICZNEGO DUŻEJ AGLOMERACJI MIEJSKIEJ}

Aktualnie funkcjonujące rozwiązania w obszarze systemu bezpieczeństwa publicznego na poszczególnych szczeblach funkcjonowania Policji dobrze wpisują się w system bezpieczeństwa państwa. Są to rozwiązania „typowe” dla każdego województwa, powiatu czy gminy, stąd trudno wymagać, żeby wychodziły naprzeciw szczególnym oczekiwaniom społeczności, które zorganizowane są w odmienny sposób. Przykładem tego rodzaju zorganizowania jest duża aglomeracja miejska, gdzie ośrodki o różnej wielkości są ze sobą funkcjonalnie połączone, stąd więc pojawiają się wspólne dla całej aglomeracji problemy z zapewnieniem bezpieczeństwa.

W poszukiwaniu rozwiązań na pojawiające się problemy i wyzwania w obszarze bezpieczeństwa aglomeracji, w szczególności w temacie optymalizacji struktury systemu bezpieczeństwa publicznego dużej aglomeracji miejskiej, wydaje się zasadnym przeprowadzenie dogłębnej analizy uwarunkowań funkcjonowania takiej struktury. W pierwszej kolejności należałoby zwrócić uwagę na ogólne oraz uniwersalne determinanty, jakie wyłaniają się dla wszystkich struktur organizacyjnych, w tym struktur organizacyjnych Policji, a następnie wskazać szczegółowe determinanty dla struktury systemu bezpieczeństwa publicznego $\mathrm{w}$ dużej aglomeracji miejskiej.

Zgodnie z teorią zarządzania, struktura każdej organizacji powinna stanowić ramy działań organizacyjnych, zarówno wykonawczych, jak i zarządczych, uwzględniając jednocześnie specyfikę procesów zachodzących wewnątrz oraz oddziaływań środowiska zewnętrznego. Ponadto powinna spełniać również funkcję regulatora działan poszczególnych składowych systemu, który tworzy daną organizację, zapewniając jednocześnie efektywną realizację celów ${ }^{15}$.

Utworzenie jednego silnego ośrodka, uwzględniającego specyfikę wielkomiejską, umożliwiłoby sprawną realizację zadań, z zakresu bezpieczeństwa publicznego w dużej aglomeracji miejskiej, przez Policję. W tym celu warto byłoby stworzyć komendy rejonowe lub okręgowe w dużych miastach, co spowodowałoby usprawnienie struktury organizacyjnej, w których skupione byłyby siły i środki, dotychczas rozproszone w wielu komendach. W tworzeniu koncepcji rozwiązania modelowego dla systemu bezpieczeństwa publicznego aglomeracji mono- i policentrycznej powinno się uwzględnić w szczególności:

- uwarunkowania formalno-prawne,

- możliwości realizacji zadań,

- rodzaje oraz charakter zagrożeń,

- oczekiwania społeczne w zakresie zapewnienia bezpieczeństwa,

- strukturę zaludnienia,

- uwarunkowania terenowe i infrastrukturalne,

- możliwości finansowe,

- rozmieszczenie sił i środków pozostających w dyspozycji Policji,

15 B.R. Kuc, Zarządzanie doskonałe, Warszawa 1999, s. 125-152; M. Maciejczak, Organizowanie, prezentacja wykładu „Podstawy zarządzania”, http://www.maciejczak.pl/download/pz-w7.pdf (01.02.2019). 
- możliwości innych systemów bezpieczeństwa.

Determinanty struktury organizacyjnej systemu bezpieczeństwa publicznego dużej aglomeracji miejskiej (żółty kolor) w zestawieniu z przyjętymi w teorii zarządzania ogólnymi determinantami struktury dowolnej organizacji (kolor niebieski) przedstawia rysunek nr 3.

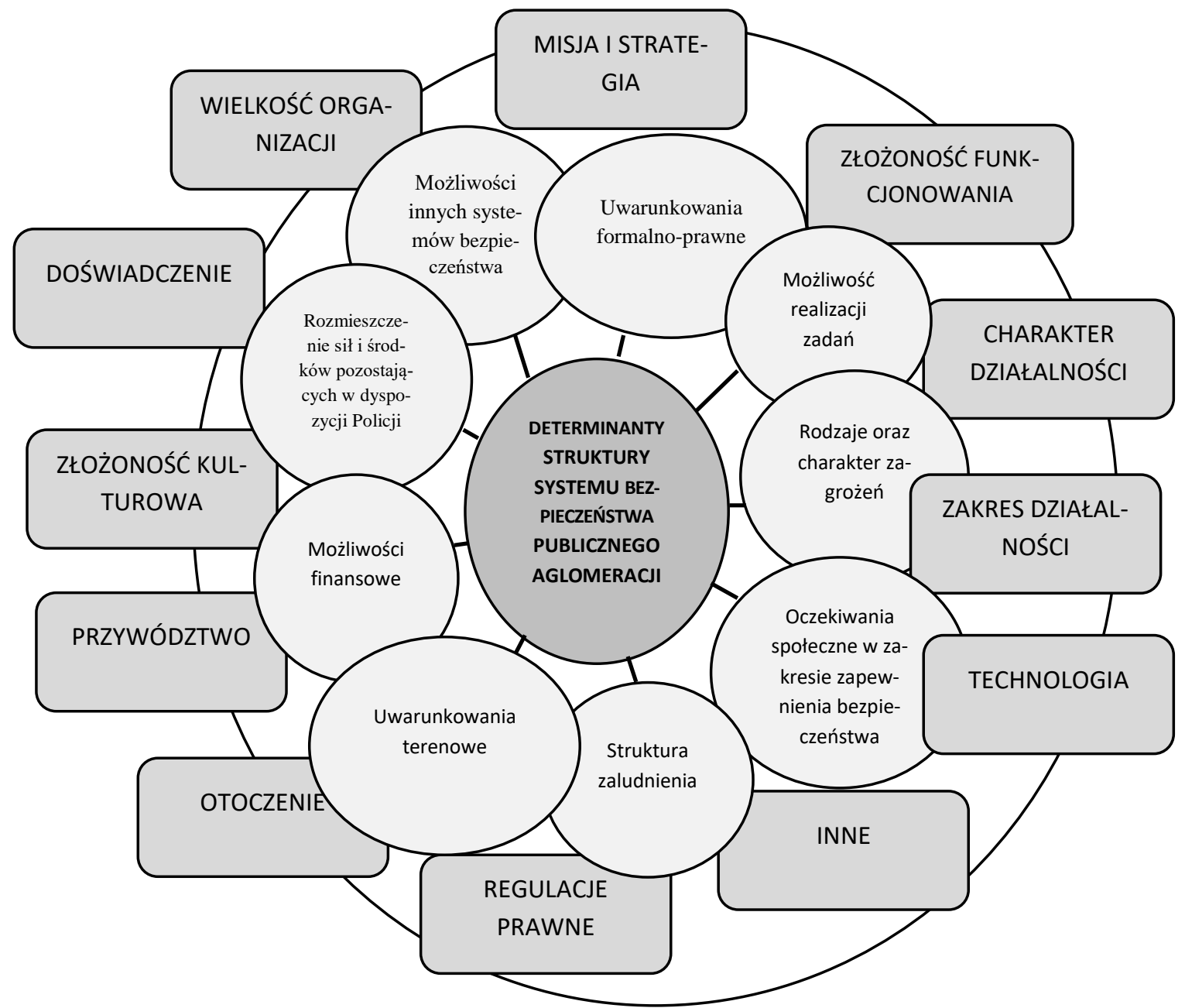

Rysunek 3. Determinanty struktury organizacyjnej systemu bezpieczeństwa publicznego dużej aglomeracji miejskiej w zestawieniu z ogólnymi determinantami dowolnej struktury organizacyjnej

Źródło: Opracowanie własne na podstawie: T. Szczurek, Od deskrypcji do antycypacji wykorzystania potencjału militarnego $w$ ksztaltowaniu bezpieczeństwa nowoczesnych wspólnot państwowych wobec rozwoju zagrożeń niemilitarnych, Warszawa 2012, s. 362.

Przeprowadzone analizy obecnie obowiązujących rozwiązań w obszarze funkcjonowania Policji wykazały, iż rozwiązania organizacyjne komend umiejscowionych w wielkich miastach opierają się na podobnym schemacie, co jest wynikiem tego, że cała organizacja i funkcjonowanie Policji opiera się na tych samych przepisach. Stąd istotą proponowanej koncepcji jest konsolidacja wysiłku Policji w realizacji zadań na rzecz bezpieczeństwa. 
Z przedstawionej idei wyłania się zasadnicze pytanie: „Gdzie powinien być umiejscowiony centralny organ Policji odpowiedzialny za bezpieczeństwo publiczne w dużych aglomeracjach?". Pytanie to nabiera szczególnego znaczenia, biorąc pod uwagę aglomeracje policentryczne, gdzie występuje kilka bądź kilkanaście miast o zbliżonej wielkości oraz potencjale. Problem ten praktycznie nie dotyczy monocentrycznych aglomeracji, w których występuje jeden dominujący ośrodek miejski. W polskich warunkach zarówno w aglomeracji policentrycznej, jak i monocentrycznej występuje miasto wojewódzkie na prawach powiatu, które jest najsilniejszym ośrodkiem oraz najczęściej jest usytuowane w centrum aglomeracji. W związku z powyższym, centralny organ Policji w dużej aglomeracji miejskiej powinien być usytuowany na szczeblu miasta wojewódzkiego.

Proponowana koncepcja systemu bezpieczeństwa publicznego w Policji w dużej mierze opiera się na rozwiązaniach przyjętych oraz sprawdzonych w Mieście Stołecznym Warszawa. Ponieważ badania empiryczne potwierdziły celowość i skuteczność takiego rozwiązania, jak również w opinii respondentów model funkcjonowania Policji w stolicy można przetransponować do innych aglomeracji, w koncepcji proponuje się utworzenie Biura Bezpieczeństwa Policji dla Aglomeracji (BBPA) podległego bezpośrednio Komendantowi Głównemu Policji. Struktura organizacyjna dopasowana byłaby do indywidualnych potrzeb aglomeracji, w której znajdowałoby się BBPA. Biuro Bezpieczeństwa Policji dla Aglomeracji posiadałoby odrębny regulamin zawierający zakres jej działania, a także strukturę, która uwzględniałaby zagrożenia występujące w danej aglomeracji. Realizowałoby zadania za pośrednictwem komend rejonowych działających na terenie aglomeracji monocentrycznej lub komend powiatowych (miejskich) na terenie aglomeracji policentrycznej. Struktura organizacyjna tych komend dopasowana byłaby do zwalczania zagrożeń, jakie są identyfikowane na danym terenie. Obszar komend rejonowych (powiatowych/miejskich) wchodzących w skład BBPA wyłączony byłby z terytorialnego zasięgu działania komendanta wojewódzkiego Policji właściwego miejscowo dla danego województwa. Idea zmian w ogólnokrajowym systemie bezpieczeństwa w Policji została przedstawiona na rysunku nr 4. 


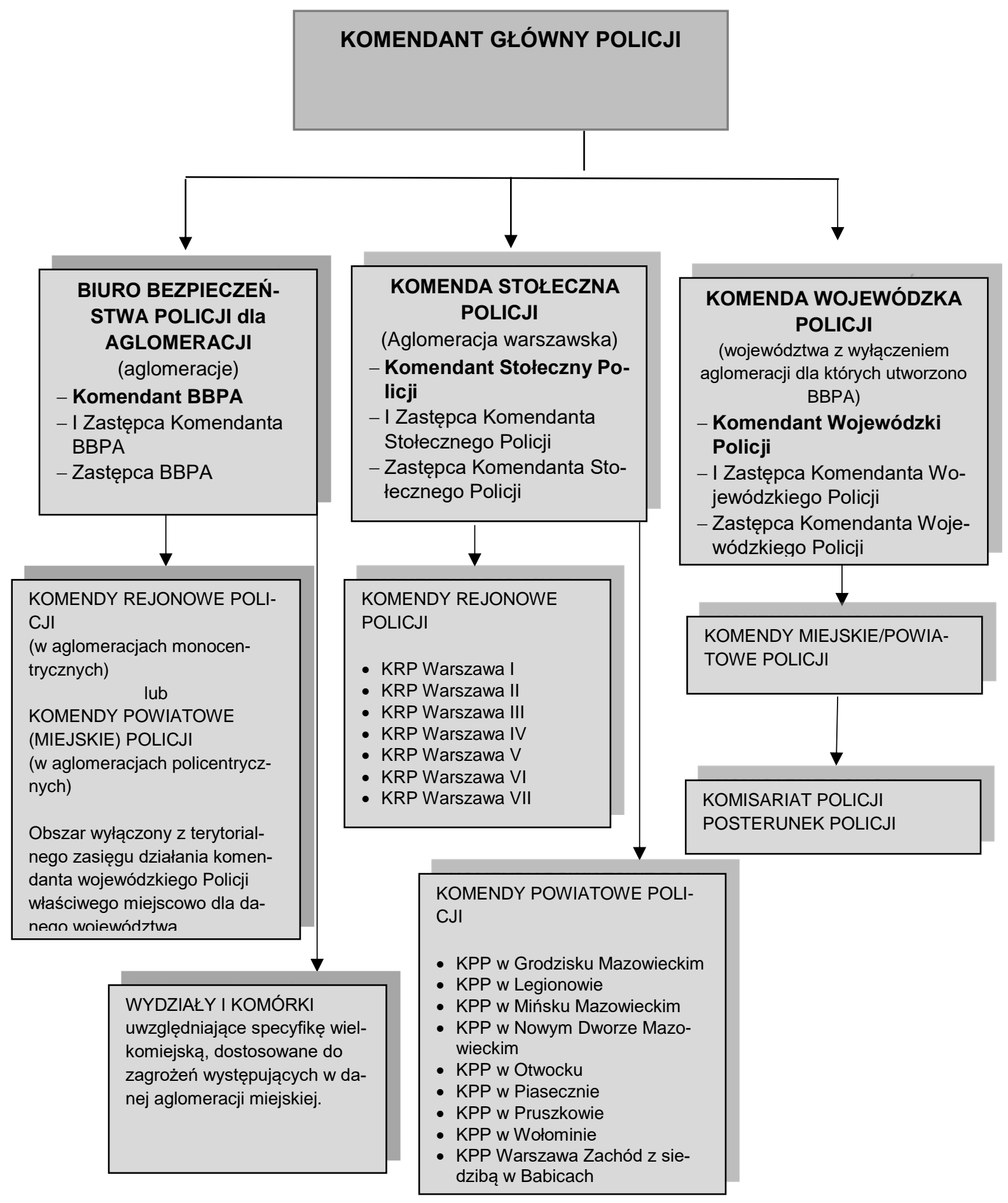

Rysunek 4. Idea zmian w ogólnokrajowym systemie bezpieczeństwa Policji proponowana struktura organizacyjna Źródło: Opracowanie własne.

Przedstawione rozwiązania wymagałyby jednocześnie wprowadzenia zmian w ustawach (przede wszystkim w ustawie $o$ Policji) w aktach wykonawczych oraz w dokumentach organizacyjno-kompetencyjnych. 


\section{Podsumowanie}

Rozwiązanie szczegółowego problemu badawczego zawartego w pytaniu: ,Jakie rozwiązania strukturalne i funkcjonalne umożliwiłyby konsolidację wysiłku Policji na rzecz bezpieczeństwa mieszkańców różnych typów aglomeracji?" - wymagało analizy struktur organizacyjnych Policji wybranych miast i miejscowości tworzących aglomeracje różnego typu oraz odpowiedzi na szereg dodatkowych pytań.

Zważywszy na specyfikę oraz odmienności poszczególnych aglomeracji miejskich w Polsce, można stwierdzić, iż możliwe jest wypracowanie wspólnych rozwiązań w postaci kompleksowego modelu dla systemu bezpieczeństwa i porządku publicznego w aglomeracjach. W szczególności rozwiązania te dotyczą Policji jako formacji odpowiedzialnej za tę sferę bezpieczeństwa narodowego. Dla uzyskania odpowiedzi na to pytanie w pracy posłużono się, między innymi, empiryczną metodą badawczą - w postaci sondażu diagnostycznego - skierowanego do funkcjonariuszy Policji.

Pierwsze pytanie dotyczyło indywidualnego dopasowania systemu bezpieczeństwa publicznego w Policji do każdej aglomeracji. Z udzielonych odpowiedzi wynika, iż zdecydowana większość ogółu policjantów jest zdania, że system bezpieczeństwa publicznego powinien być indywidualnie dopasowany do każdego województwa z uwzględnieniem występowania na jego terenie dużej aglomeracji miejskiej. Takiego samego zdania byli komendanci Policji, którzy wskazali, że system powinien być dostosowany do lokalnych uwarunkowań. Zarówno w zakresie struktur i naliczeń etatowych, jak i realizacji ustawowych zadań wychodzących naprzeciw oczekiwaniom społecznym.

Drugie pytanie dotyczyło bezpośredniej opinii osób badanych w zakresie możliwości przeniesienia rozwiązań funkcjonujących w stołecznej Policji do komend w innych aglomeracjach miejskich w Polsce. Zdecydowana większość funkcjonariuszy Policji opowiedziało się za możliwością transferu tychże rozwiązań.

Nowy model Policji związany z konsolidacją wysiłku tej formacji w realizacji zadań na rzecz bezpieczeństwa, składałby się z czterech poziomów adekwatnie do zorganizowania Policji w Polsce, tj. Komendy Głównej Policji, komend wojewódzkich/stołecznej Policji/biura bezpieczeństwa Policji dla aglomeracji, komend powiatowych/rejonowych Policji i komisariatów/posterunków Policji. Dla każdego z nich określony zostałby zakres, a także charakter realizowanych zadań, przede wszystkim z uwzględnieniem poziomu organizacyjnego w ramach systemu hierarchicznego podporządkowania funkcjonującego w Policji. Dodatkowo ważne jest zapewnienie:

- wystandaryzowanych struktur organizacyjnych we wszystkich jednostkach Policji odpowiedzialnych za realizację przedsięwzięć związanych z zapewnieniem bezpieczeństwa publicznego,

- zwrócenie szczególnej uwagi na potrzebę wzmocnienia realizacji zadań na rzecz bezpieczeństwa w dużych aglomeracjach miejskich przez Policję na poziomie komend rejonowych Policji mających realny wpływ na wzrost poczucia bezpieczeństwa wśród społeczeństwa, 
- inicjowanie oraz prowadzenie działań przez Policję, których struktura organizacyjna dopasowana byłaby do zwalczania zagrożeń, jakie są identyfikowane w danym mieście, a także zgodnie z potrzebami i oczekiwaniami ze strony lokalnej społeczności.

Warto wskazać, że na najwyższym poziomie hierarchicznym osoby, które są odpowiedzialne za obszar funkcjonowania Policji, będą koncentrowały się na zadaniach, które dotyczą np. analizy zagrożeń na terenie podległym Biuru Bezpieczeństwa Policji dla danej aglomeracji, a następnie, opierając się na ich wynikach, określenie rozwiązań strukturalnych i funkcjonalnych, które należałoby wdrożyć, aby zwiększyć bezpieczeństwo mieszkańców. Natomiast na poziomie komend powiatowych/rejonowych/miejskich dominowałyby zadania dotyczące analizy oraz diagnozy zagrożeń występujących na podległym terenie.

Reasumując, struktury organizacyjne Policji powinny być indywidualnie dopasowane do każdej aglomeracji. Można spróbować przenieść rozwiązania funkcjonujące w stołecznej Policji do komend znajdujących się w innych dużych aglomeracjach w Polsce. Ideą towarzyszącą wdrożeniu wskazanej koncepcji byłoby zoptymalizowanie struktur Policji dostosowane do rzeczywistych potrzeb, przy jednoczesnym uniknięciu dublowania zadań funkcjonariuszy poszczególnych jednostek organizacyjnych, które funkcjonują w tym samym rejonie odpowiedzialności. Pozwoliłoby to na organizację przejrzystej struktury Policji oraz zakresów odpowiedzialności, a także podległości na poszczególnych poziomach kierowania/dowodzenia, $\mathrm{w}$ tym na poziomie dużej aglomeracji miejskiej. Taka centralizacja rejonowa zdecydowanie może przyczynić się do poprawy bezpieczeństwa oraz usprawni działania funkcjonariuszy Policji i służb z nią współpracujących.

Autorka wyraża przekonanie, że wprowadzenie proponowanych zmian i rozwiązań do obowiązującego porządku prawnego przyczyniłoby się do usprawnienia funkcjonowania Policji w Polsce, podniosłoby zdolności w reagowaniu na zagrożenia dla porządku i bezpieczeństwa publicznego, jednocześnie przynosząc wymierne korzyści finansowe i społeczne.

Kluczowe znaczenie dla Autorki publikacji było uzyskanie zadowalającej odpowiedzi respondentów na pytanie dotyczące indywidualnego dopasowania systemu bezpieczeństwa publicznego w aglomeracjach oraz możliwości transferu rozwiązań stolicy na rzecz innych aglomeracji miejskich. Wynikało to z faktu, iż w zamyśle Autorki koncepcja rozwiązania modelowego dla systemu bezpieczeństwa publicznego dużej aglomeracji miejskiej była oparta właśnie na rozwiązaniach przyjętych i sprawdzonych w warszawskiej Policji.

W opracowaniu koncepcji rozwiązania modelowego dla systemu bezpieczeństwa publicznego dużej aglomeracji miejskiej uwzględniono między innymi specyfikę funkcjonowania aglomeracji, a w szczególności: uwarunkowania formalno-prawne, możliwość realizacji zadań, rodzaje oraz charakter zagrożeń, oczekiwania społeczne w zakresie zapewnienia bezpieczeństwa, strukturę zaludnienia, uwarunkowania terenowe i infrastrukturalne, możliwości finansowe, rozmieszczenie sił i środków pozostających w dyspozycji Policji oraz możliwości innych systemów bezpieczeństwa. Istotą zaproponowanej koncepcji była konsolidacja wysiłku Policji 
W realizacji zadań na rzecz bezpieczeństwa publicznego. W celu realizacji zadań na obszarze aglomeracji zaproponowano utworzenie Biura Bezpieczeństwa Policji dla Aglomeracji (BBPA). Biuro podlegałoby Komendantowi Głównemu Policji, a także realizowałoby zadania za pośrednictwem komend rejonowych (w aglomeracjach monocentrycznych) lub komend powiatowych/miejskich (w aglomeracjach policentrycznych) działających na terenie aglomeracji.

Takie zmiany organizacyjne oraz legislacyjne powinny uwzględniać powołanie komend rejonowych Policji w aglomeracjach. Spowodowałoby to usprawnienie struktury organizacyjnej, a także skupiło rozproszone siły i środki w strukturach uwzględniających specyfikę dużych aglomeracji miejskich. Będzie to przedmiotem rozważań w kolejnym rozdziale dysertacji.

\section{BIBLIOGRAFIA}

Czapska Janina, Wójcikiewicz Józef. 1999. Policja w społeczeństwie obywatelskim. Zakamycze: Wydawnictwo Kantor.

Izdebski Hubert. 1996. Historia administracji. Warszawa: A. Liber.

Komisariaty Specjalistyczne. http://policja.waw.pl/pl/stoleczna-policja/komisariaty-specjalisty/330,Komisariaty-Specjalistyczne.html

Kuc Bolesław Rafał. 1990. Zarządzanie doskonałe. Warszawa: Oskar-Master of Business.

Łuczyszyn Andrzej, Łuczyszyn Tomasz. 2019. Miasta jako przestrzenie kumulacji przestępczości. W Bezpieczeństwo antyterrorystyczne budynków użyteczności publicznej. T. 3 Terroryzm, zamachy, sprawcy vs sposoby minimalizacji skutków. (red.) Wiśniewska-Paź Barbara, Stelmach Jarosław. Toruń: Wydawnictwo Adam Marszałek.

Maciejczak Mariusz. 2016. Organizowanie, prezentacja wykładu „Podstawy zarządzania”. http://www.maciejczak.pl/download/pz-w7.pdf

Obwieszczenie Komendanta Głównego Policji z 25 czerwca 2013 r. w sprawie ogłoszenia jednolitego tekstu zarządzenia komendanta głównego Policji w sprawie szczegółowych zasad organizacji i zakresu działania komend, komisariatów i innych jednostek organizacyjnych Policji, (Dz. Urz. KGP poz. 50.).

Pieprzny Stanisław. 2003. Policja. Organizacja i funkcjonowanie. Zakamycze: Kantor Wydawniczy. Pokruszyński Witold, Straszewski Kazimierz, Terlikowski Tomasz. 1996. System bezpieczeństwa publicznego Polski, Warszawa: AON.

Skiba Ferdynand. 2015. Policja w Polsce. Działalność formacji na obszarze aglomeracji miejskich. Szczytno: WSPol.

Urban Andrzej. 2017. Kształtowanie bezpiecznych przestrzeni miejskich. W Bezpieczne miasta: współczesne zagrożenia i wyzwania, (red.) Kustra Witold, Smolak Leszek. Warszawa: Akademia Obrony Narodowej.

Zarządzenie nr 1041 Komendanta Głównego Policji z 28 września 2007 r., wyd. cyt., § 30 i 31 - to szczegółowy wykaz zadań, jakie spoczywają na komendach powiatowych, w tym miejskich i komisariatach Policji.

Zarządzenie nr 88 Komendanta Głównego Policji z 1 lutego 2011 r. w sprawie zasad naliczeń etatowych w Policji, (Dz. Urz. KGP nr 2, poz. 7). 